\title{
LA PINTURA: POEMA DIDÁCTICO EN TRES CANTOS (1786) DE DIEGO ANTONIO REJÓN DE SILVA. UNA RELECTURA A TRAVÉS DE SUS PARATEXTOS
}

\section{La Pintura: poema didáctico en tres cantos (1786) by Diego Antonio Rejón de Silva. A Re-Reading over the Metatexts}

\author{
Alejandro JAQUERO ESPARCIA \\ Universidad de Castilla-La Mancha \\ alejandro.jaquero@uclm.es
}

Fecha de recepción: 13/12/2019

Fecha de aceptación definitiva: 10/05/2020

RESUMEN: La aportación del ilustrado Diego Antonio Rejón de Silva al debate teórico-artístico del siglo XVIII merece una especial atención, sobre todo uno de sus principales trabajos: La Pintura: poema didáctico en tres cantos (1786). Su labor se enmarca en la moda dieciochesca de generar estructuras de conocimiento versificadas o "poemas prosaicos». Aunque el sistema poético utilizado por el autor resulta interesante, pensamos que la obra puede presumir de otras características. Proponemos un análisis aproximativo a la teoría artística del autor a través de los paratextos que acompañan el poema, con el fin de comprender la herencia asimilada de la tratadística italiana; la síntesis de las ideas artísticas asimiladas en el Barroco español por autores como Francisco Pacheco, Vicente Carducho o Acisclo Antonio Palomino, y la interpretación propia del arte de su tiempo.

Palabras clave: Diego Antonio Rejón de Silva; paratextos; Ilustración; teoría de la pintura; poesía didáctica. 
ABSTRACT: The contribution of Diego Antonio Rejón de Silva to the theoretical and artistic debate of the $18^{\text {th }}$ century deserves special attention, especially one of his major works redacted on poetic structure: La Pintura: poema didáctico en tres cantos (1786). His work belongs to the Age of Reason trend of generating new knowledge structures by making versified or "prosaic poems". We are proposing to analyze approximatively the artistic theory of the author through the metatexts that accompany his work, in order to understand the heritage of Italian treatises, synthesis of artistic ideas assimilated by Spanish Baroque authors like Francisco Pacheco, Vicente Carducho or Acisclo Antonio Palomino and the interpretation of the art of their time.

Key words: Diego Antonio Rejón de Silva; Metatexts; Enlightenment; Painting Theory; Didactic Poetry.

La corriente académica y erudita desarrollada en España a lo largo del siglo XVIII generó un vasto caudal de reformulaciones teóricas en la inmensa mayoría de disciplinas. Comenzando en la educación y pasando por la literatura, teología, ciencias y, para nuestro interés particular, las artes. La raíz del conocimiento renovado arraigó en el territorio español gracias a las grandes personalidades que hicieron del Siglo de las Luces una centuria revolucionaria desde una óptica cultural. Fueron un buen ejemplo de ello las labores emprendidas por personalidades de la talla del conde de Campomanes en lo referente a la educación de las clases populares, las especulaciones filosóficas de fray Benito Jerónimo Feijoo o los debates sobre historia y literatura surgidos de la pluma de Gregorio Mayans y Siscar. En definitiva, una serie de espacios para el desarrollo de la razón y la ciencia que también fueron propicios en el ámbito de la tratadística de las artes, tal y como sucede con la labor del ilustrado Diego Antonio Rejón de Silva y su La Pintura: poema didáctico en tres cantos (1786). En este poema didascálico, el autor propone una serie de meditaciones encomiásticas y teóricas sobre el arte de la pintura en consonancia con el ideario artístico de su época.

Aunque el sistema utilizado para expresar su interpretación del arte resulta por sí mismo original, en las siguientes páginas proponemos el análisis del conjunto de elementos paratextuales que conforman el propio poema didáctico. Pensamos que, además de la relevancia del ideario artístico expresado en los versos didascálicos, es necesario prestar atención a diversas partes de la obra impresa que profundizan en la transmisión del mensaje pedagógico. A través de estos elementos que complementan el poema iremos viendo cómo se articula el ideario teórico del escritor y se plasman las diversas opiniones críticas sobre el arte de la pintura en el discurso que buscó expresar, más allá de los versos que componen la obra.

Dichas reflexiones surgen en un contexto preciso de mezcolanza con las corrientes estéticas de origen europeo y la estima por el arte nacional, la mirada a la estética del pasado hispano. El asentamiento del poder borbónico conllevó 
una paulatina transformación hacia un nuevo gusto que fue recogido por un pensamiento artístico en renovación; sin embargo, esta nueva realidad tuvo que convivir con la herencia precedente. A comienzos de la centuria el legado teórico del Barroco perduraba en la labor de Antonio Palomino y el Museo Pictórico y Escala Óptica: el conocimiento teórico y práctico sobre la pintura y, a su vez, las biografías de pintores y escultores iniciando un movimiento de revaloración artística nacional ${ }^{1}$. Una revalorización del arte nacional que tiene continuidad a mediados del Setecientos en Gaspar Melchor de Jovellanos. Los temas de interés tratados por el ilustrado fueron de gran amplitud y relacionados con la mayoría de las materias del saber, siendo destacada su aportación al discurso de las artes dieciochescas ${ }^{2}$. En referencia al arte pictórico, la oración pronunciada durante el discurso de ingreso al puesto de académico de honor en la Real Academia de Bellas Artes de San Fernando, expuesta el 14 de julio de 1780 ante los académicos, formula la revalorización de la idea del arte hispano que había comenzado a fraguarse a mediados de la centuria, confrontando la opinión crítica generada a nivel internacional ${ }^{3}$. En sintonía con esta actitud, Antonio Ponz concibió El Viaje de España (1772-1794), monumental labor para el conocimiento del patrimonio artístico español, emitiendo una serie de valoraciones críticas con un marcado pensamiento ilustrado ${ }^{4}$.

En este sentido, muchos de los textos surgidos durante estos años recurren a elementos paratextuales que permitan consolidar el saber expresado. Hay algunos ejemplos de gran importancia en la literatura artística precedente, de los que cabría destacar las aportaciones de Vicente Carducho en sus Diálogos de la Pintura

1. Pese a que por desgracia todavía no contamos con una edición crítica de los textos de Palomino, son muchos los trabajos que han abordado de manera parcial el análisis de su teoría. Sirvan de ejemplo LeÓn Tello, Francisco José y SANZ Sanz, María Virginia. La teoría española en la pintura en el siglo XVIII: el tratado de Palomino. Madrid: Universidad Autónoma, 1979; para una visión de conjunto, GaYa NuÑo, Juan Antonio. Vida de Acisclo Antonio Palomino: el historiador, el pintor: descripción y crítica de sus obras. Córdoba: Diputación Provincial, 1981; Morán Turina, José Miguel. «El rigor del tratadista: Palomino y el Museo Pictórico". Anales de Historia del Arte, 1996, 6, pp. 282-283 y ÚBEDA DE Los Cobos, Andrés. Pensamiento artístico español del siglo XVIII. De Antonio Palomino a Francisco de Goya. Madrid: Aldeasa, 2001, pp. 19-30.

2. ARCO, Ricardo del. "Jovellanos y las bellas artes». Revista de Ideas Estéticas, 1946, 6, pp. 31-64; Barón Thaidigsmann, Francisco Javier. Ideas de Jovellanos sobre arquitectura. Oviedo: Gobierno del Principado de Asturias, 1985; GonzÁlez SANTOS, Javier. Jovellanos, aficionado y coleccionista. Gijón: Fundación Municipal de Cultura, Educación y Universidad Popular, 1994; ÚBeda DE Los CoBos. Pensamiento artístico..., op. cit., pp. 405-415; Jovellanos, Gaspar Melchor de. Memorias histórico-artísticas de arquitectura. Ed. Daniel Crespo Delgado y Joan Domenge i Mesquida. Madrid: Akal, 2013, pp. 13-142, y Cerra BreA, Miriam. "Jovellanos y Ceán Bermúdez, hacia una historia de las artes en España». Anuario del Departamento de Historia y Teoría del Arte, 2014, 26, pp. 55-68.

3. García Melero, José Enrique. Arte español de la Ilustración y del siglo XIX. En torno a la imagen del pasado. Madrid: Ediciones Encuentro, 1998, p. 13.

4. Crespo Delgado, Daniel. Un viaje para la Ilustración. El Viaje de España (1772-1794) de Antonio Ponz. Madrid: Marcial Pons, 2012 
(1633) o Francisco Pacheco en el Arte de la Pintura (1649), ambos textos profusamente completados con notas aclarativas de las fuentes utilizadas, pero también de puntualizaciones subjetivas. A propósito de Carducho, el tratadista florentino complementó el discurso de su obra incluyendo al final una serie de poemas y grabados que sintetizaban la teoría expuesta en los diálogos ${ }^{5}$. Las obras de Palomino, Jovellanos o Ponz recurren a notas con un carácter similar, lo que les permite clarificar la información generada. Con ello lograron ampliar noticias específicas sobre algunos hechos remarcables o bien expresar opiniones concretas. Así, Palomino incluye en los prólogos de sus tratados las justificaciones y motivaciones que lo llevaron a prepararlos, en algunos casos como en el del Parnaso Pintoresco añadiendo datos sobre las fuentes consultadas ${ }^{6}$.

Inmersos ya en la experiencia concerniente al pensamiento y las letras del siglo XVIII, la inclusión reiterativa de estos materiales metatextuales se nutrió de la necesidad de justificar el origen de los conocimientos publicados, permitiendo una difusión clara y útil para el lector que buscase instruirse. De igual modo, los verdaderos hombres de letras demostraban a través de las citas su dominio de la bibliografía y las fuentes, haciendo gala de sus propiedades intelectuales ${ }^{7}$. El perfil de escritor intelectual precisaba la demostración del bagaje cultural adquirido, puesto que ello suponía marcar una importante diferencia con aquellos falsos eruditos o violetos, denominación satírica surgida de discursos literarios como los de José de Cadalso ${ }^{8}$. Aunque algunos autores a comienzos de la etapa ilustrada, sirviéndonos de muestra la labor del padre Feijoo, trataron de ir eliminando de sus reflexiones los aparatos críticos de notas, gran parte de ellos hicieron un uso reiterativo de estas herramientas del lenguaje escrito?. Con ello consiguieron elaborar una serie de trabajos en los que depositaron las esperanzas de poder mejorar la sociedad en la que convivían, prestando instrumentos útiles para el progreso sociocultural y la formación de todos los estamentos ${ }^{10}$.

5. Portús PÉrez, Javier. "Painting and Poetry in Diálogos de la Pintura». En Andrews, Jean; RoE, Jeremy y WooD, Oliver Noble (eds.). On Art and Painting. Vicente Carducho and Baroque Spain. Wales: University of Wales Press, 2016, pp. 71-90.

6. Palomino, Acisclo Antonio. Parnaso pintoresco laureado con las vidas de los pintores y estatuarios eminentes españoles. Madrid: Viuda de Juan García, 1724, vol. III, pp. 232-234.

7. Álvarez Barrientos, Joaquín. "La figura del escritor en el siglo XVIII". Cuadernos de Ilustración y Romanticismo, 1992, 2, pp. 14-15.

8. Álvarez Barrientos, Joaquín. Los hombres de letras en la España del siglo XVIII. Apóstoles y arribistas. Madrid: Castalia, 2006, pp. 55-71, e INSÚA, Marcela. "La falsa erudición en la Ilustración española y novohispana: Lizardi». Estudios Filológicos, 2011, 48, pp. 61-79.

9. RuEDA, Ana. "Cartas y cartapacios: la crítica literaria del siglo XVIII ante la "vana erudición" del coleccionismo». Cuadernos de Ilustración y Romanticismo, 2015, 21, p. 17.

10. SARRAIH, Jean. "La notion de l'utile dans la culture espagnole à la fin du XVIII siècle». Bulletin Hispanique, 1948, 50 (3-4), pp. 495-509, y CRESPO DELGADO, Daniel. "Lectores y noticias sobre bellas artes en los papeles periódicos españoles de la Ilustración». En MaEsTRE MAESTRE, José María; Díaz GiTO, Manuel Antonio y ROMERo FERRER, Alberto (eds.). Francisco Mariano Nipho. El nacimiento de la prensa 
Pese a que la estructura del tratado de artes ilustrado español fue deudora, en algunos aspectos, de sus predecesores barrocos, los aparatos paratextuales fueron más abundantes que en las publicaciones anteriores, sobre todo aquellos elaborados a partir de la segunda mitad del siglo XVIII. De este modo, Ponz añade profusas notas aclarativas en sus Viajes, espacio paratextual en el cual termina reflejándose su opinión personal. Por ejemplo, en el tomo I nos describe su valoración sobre la labor artística del tratadista cordobés autor del Museo Pictórico:

D. Antonio Palomino es digno de muchas alabanzas por lo que pintó, y por lo que escribió; y aunque cometió varias equivocaciones, principalmente en su tratado de las Vidas de los Pintores, faltando asimismo las de muchos, que merecian lugar en él; sin embargo, su gran mérito es acreedor á que se disimulen estos defectos, que naturalmente se originaron de las relaciones que le enviaban para su obra ${ }^{11}$.

En este caso concreto Ponz señala ciertos aspectos con la idea de enfatizar la labor de Palomino. Estas dinámicas en las que el autor desea mostrar todo su bagaje intelectual serán comunes a lo largo de los Viajes, extendiéndose a otros escritos suyos. Lo observamos en la edición que plantea de los Comentarios de la Pintura Antigua de Felipe de Guevara en 1788, aportando su posicionamiento en criterios artísticos y manteniéndose presente su oposición a la construcción de retablos en madera ${ }^{12}$. El uso reiterado de este aparato paratextual, en el cual se buscaba marcar un sello de erudición, lo vemos en otros textos de carácter artístico. Jovellanos añadió en la versión impresa de la oración leída durante el acto de entrega de premios de la Academia de San Fernando una serie de notas que justifican los aspectos tratados en su lección. Desarrollan una actitud crítica frente al arte, además de sugerir nuevos enfoques para futuras investigaciones ${ }^{13}$.

y de la crítica literaria periodística en la España del siglo XVIII. Alcañiz-Madrid: Instituto de Estudios Humanísticos y CSIC, 2015, p. 209.

11. Ponz, Antonio. Viage de España, o cartas, en que se da noticia de las cosas mas apreciables, $y$ dignas de saberse que hay en ella. Madrid: Joachim Ibarra, 1772, vol. I, p. 77.

12. "Qué diria este Licinio, si reviviese en nuestros tiempos, como Vitruvio hubiera querido que reviviese en los suyos, y entrando, no digo en nuestros teatros, sino en los lugares mas sacrosantos, como son los Templos, los viese tan llenos de ideas monstruosas i de tantos retablos disparatados, y otros ornatos llevados á efecto por locas imaginaciones mas ridiculas sin duda que las de Apaturio? ¿Qué diria, digo yo? Creo que no se habia de contentar con medirnos del mismo modo que á los Alabandenos, sino que nos trataría mucho peor que á aquellos, por haber tenido ojos de sufrir en tan santos lugares semejantes disparates, tan contrarios á la razon y á todo buen sentido». GuEvarA, Felipe de. Comentarios de la Pintura. Ed. A. Ponz. Madrid: D. Gerónimo Ortega, Hijos de Ibarra y Compañía, 1788 , p. 72.

13. Esto ocurre cuando inicia el discurso del arte de la Antigüedad romana: «La averiguación de las causas que estorbaron los progresos de las bellas artes entre los romanos pudiera dar digna materia a una disertación». Jovellanos, Gaspar Melchor de. Elogio de las Bellas Artes. Intr. Javier Portús Pérez. Madrid: Casimiro, 2014, p. 46. 


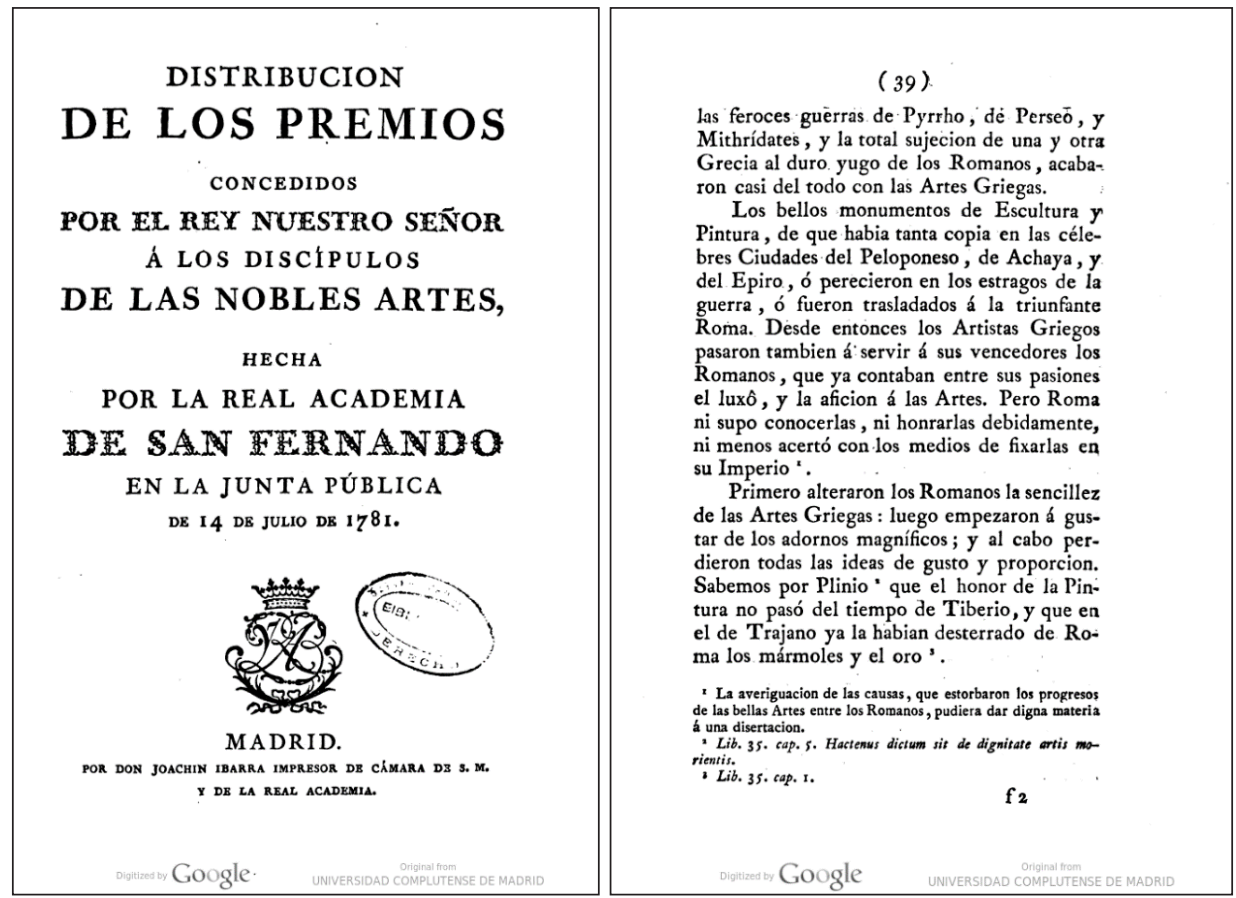

Figs. 1 y 2. Gaspar Melchor de Jovellanos. Portada y ejemplo del uso de notas aclarativas en el texto del «Elogio de las Bellas Artes». En Distribución de los premios concedidos por el rey nuestro señor a los discípulos de las Nobles Artes echa por la Real Academia de San Fernando en la Junta Pública de 14 de Julio de 1781. Madrid: don Joaquín Ibarra, 1781, p. 38. Fuente: Universidad Complutense de Madrid.

Del mismo modo, Ceán Bermúdez utilizó en el Diccionario bistórico de los más ilustres profesores de las Bellas Artes en España estos recursos paratextuales para añadir fragmentos de textos e información precisa acerca de las biografías de $\operatorname{artistas}^{14}$. En las ediciones y traducciones de textos sobre las artes elaboradas por él mismo no abandona este sistema metalingüístico. Así, en su traducción de la obra de Francesco Milizia Dell'arte di vedere nelle Belle Arti del Disegno (1781) publicada en 1827 nos hace partícipes de sus reflexiones teóricas. Es más, en dicha traducción la cantidad de aparato crítico fue considerablemente mayor que el texto traducido, llegando a restarle protagonismo.

14. García LÓPEZ, David. "El Diccionario Histórico de los más ilustres profesores de las Bellas Artes en España. En SANTIAgo PÁEz, Elena María (coord.). Ceán Bermúdez. Historiador del arte y coleccionista ilustrado. Madrid: Biblioteca Nacional de España-Centro de Estudios Europa Hispánica, 2016, pp. 225-245. 

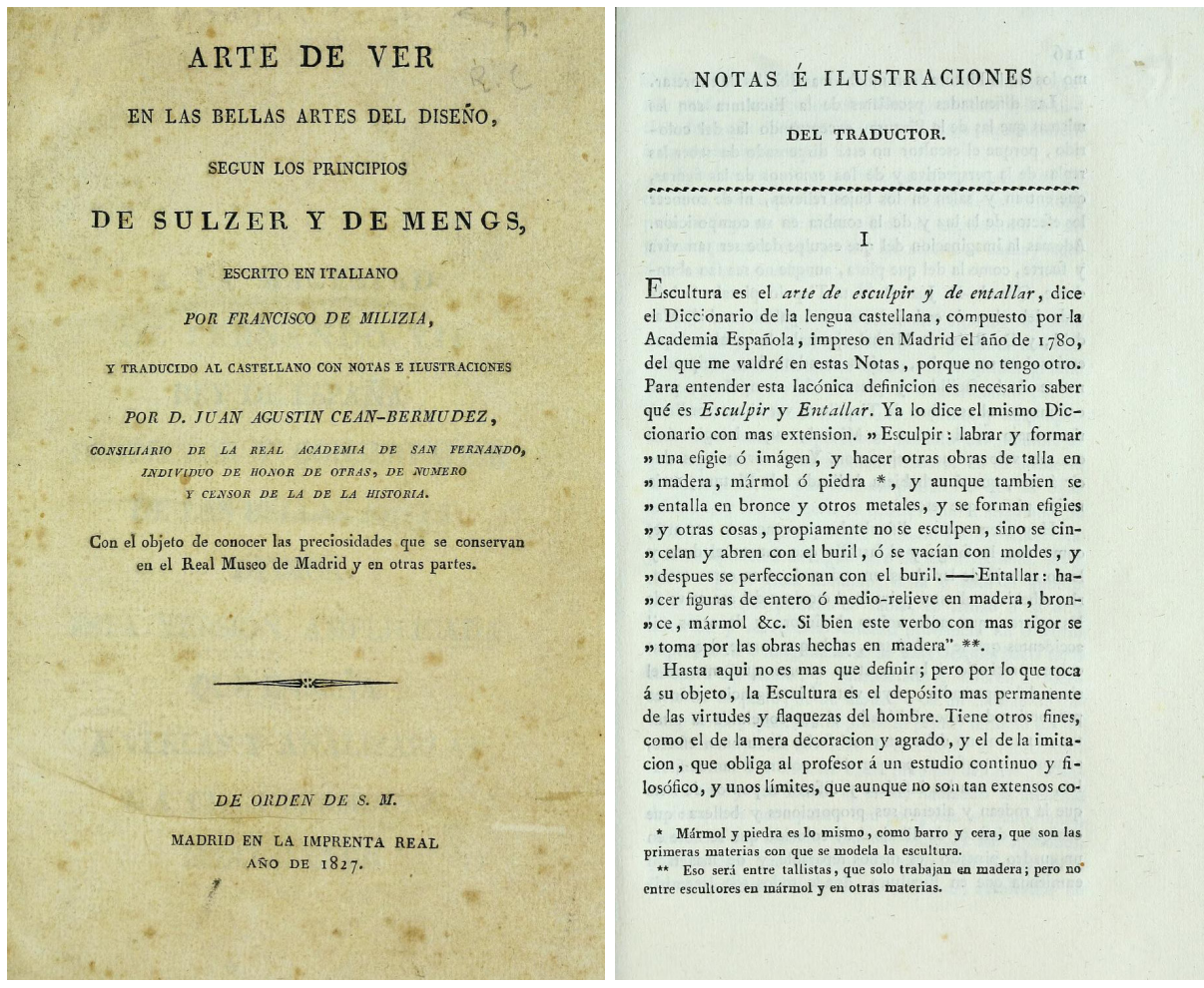

Figs. 3 y 4. Francisco Milizia. Portada e inicio del apéndice de notas aclaratorias del texto. En Arte de ver en las bellas artes del diseño: segun los principios de Sulzer y de Mengs.

Ed. Juan Agustín Ceán Bermúdez. Madrid: Imprenta Real, 1827, p. 115. Fuente: Getty Research Institute (Los Angeles, Ca.).

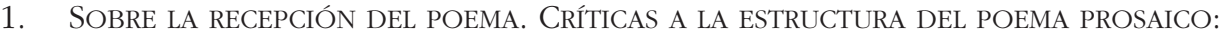 LA MINUSVALORACIÓN DEL APARATO PARATEXTUAL}

Antes de iniciar el análisis propuesto, es preciso hacer un breve recorrido por la fortuna crítica del texto con el fin de observar las características valoradas en el poema por sus comentadores. Las opiniones vertidas sobre el papel que tuvo Rejón de Silva y su poema en el debate teórico-artístico de la época no han sido abundantes, condicionadas en su mayoría por la minusvaloración de la teoría artística filtrada a través de una estructura versificada no comprendida por la crítica. En 1789 aparece una primera valoración de su obra elaborada por Juan Sempere y Guarinos en el Ensayo de una biblioteca española. El resumen prefiere destacar el valor del contenido teórico que su estilo lírico, del que nos interesa especialmente el comentario final sobre el poema: 
No contento el Señor Rejón con haber traducido las obras antecedentes, para facilitar mas los progresos de las Nobles Artes, á las que es sumamente apasionado; ha recogido los preceptos que se encuentran en los mejores Autores, y ha escrito este Poema, en el qual se explican los elementos de la dificil Arte de la Pintura con la mayor sencillez y claridad; y se proponen los mejores modelos que deben imitarse despues del estudio del natural, el qual se recomienda como el mas principal [...] Al fin añade varias notas para la mayor explicacion de algunos lugares del Poema, y en una de ellas defiende el mérito de los Españoles en la Pintura, manifestando las equivocaciones y falta de noticias de algunos extrangeros, al hablar de nuestros Pintores ${ }^{15}$.

El primero de los historiadores y críticos de arte que hace mención a su figura fue Ceán Bermúdez en el Diccionario, registrando no solo su aportación escrita, sino subrayando también su pasión por el dibujo ${ }^{16}$. Destacó del trabajo erudito de Rejón las traducciones realizadas por aquel de los textos de Leon Battista Alberti y Leonardo da Vinci, junto a la confección de su Diccionario de las Nobles Artes para instrucción de los Aficionados, y uso de los Profesores (1788). La valoración emitida por Ceán sobre el poema didáctico no demostró mayor entusiasmo: «Su afecto extraordinario a la pintura y á la poesía le induxo á publicar un poema didáctico del arte de la pintura, que anda tambien impreso, tan difícil de desempeñar, como fue fácil de emprender ${ }^{17}$. Podemos determinar que la estimación con la que define el escritor asturiano el poema de Rejón fue bastante baja. Una crítica vinculada a la desprestigiada lírica del texto, puesto que se menosprecia el estilo poético didascálico más que la valoración acerca de la teoría artística allí expuesta.

A mediados del siglo XIx hallamos otras noticias a propósito del poema de Rejón, pero en este caso fueron efectuadas desde fuera de España. En 1849, George Ticknor recoge una pequeña nota informativa mientras desarrolla sus observaciones sobre los poemas didácticos. Hablando del poema La Música (1779) de Tomás de Iriarte le permite recordar a pie de página la aportación del ilustrado madrileño:

As a sort of counterpart to the poem on Music, by Iriarte, may be mentioned one of less merit, published son afterwards by Don Diego Antonio Rejón de Silva, La Pintura. Poema Didáctico en Tres Cantos, (Segovia, 1786, 8vo.,) the first canto being on Design, the second on Composition, and the third on Colouring, with notes and a defence of Spanish artists ${ }^{18}$.

15. Sempere y Guarinos, Juan. Ensayo de una biblioteca española de los mejores escritores del reinado de Carlos III. Madrid: Imprenta Real, 1789, v. V, pp. 3-5.

16. «Le hemos visto en Madrid dibuxar y copiar con acierto las obras de Mengs, de lo que existe alguna prueba en la real academia de S. Fernando». CEÁn BERMúdeZ, Juan Agustín. Diccionario histórico de los más ilustres profesores de las Bellas Artes en España. Ed. José Miguel Morán Turina. Madrid: Akal, 2001, pp. 164-165.

17. CEÁn Bermúdez, Diccionario..., op. cit., p. 164

18. TiCKNOR, George. History of Spanish Literature. New York: Frederick Ungar Publishing Co., 1849, p. 258. 
El poema de Rejón es definido de menor mérito comparado con la obra de Iriarte, algo que nos parece comprensible, dado que se vuelve a estimar el lirismo frente al contenido. Un argumento obvio hablándose de un trabajo de crítica literaria. Algo parecido ocurre en el Dictionnaire Historique des Hommes qui se sont fait un nom, obra iniciada en el siglo XVIII por François Xavier de Feller y continuada en 1848 por Claude-Ignace Busson y Charles Weiss. Aunque toma gran parte de la información general de Ceán, sí que expresa una valoración propia del poema:

Il avait formé une magnifique collection de tableaux, et il se plaisait à recevoir chez lui les articles auxquels il prodiguait les conseils et les encouragements. Dans ses loisirs, il cultivait les lettres et la poésie avec succès. Son poème de la Peinture, Ségovie, 1786, in-8, est un ouvrage estimable pour lequel il a beacoup profité, comme il le déclare lui-même, des poèmes de Lemierre, de Watelet et de Dufresnoy ${ }^{19}$.

El análisis de la teoría artística de Rejón de Silva fue retomado a nivel nacional por Marcelino Menéndez Pelayo en la Historia de las ideas estéticas en España (1883-1889). Pese a expresarse de manera breve y poco objetiva, para Menéndez Pelayo la obra del ilustrado madrileño fue un ejercicio pésimo de imitación lírica en comparación con la labor emprendida siglos antes por Pablo de Céspedes. En su opinión, a nivel teórico no aporta demasiado dentro del discurso artístico de su época; arrastrado por las corrientes de poesía didascálica surgidas en el siglo ilustrado, pretende imitar la labor de algunos poetas didácticos franceses como Watelet o Lemierre, pero cayendo en un prosaísmo fatal. Ahora bien, afirma que si hubiera escrito su tratado en prosa podría haber pasado por una buena teoría de la pintura elemental. Asimismo, no descarta que haya tomado excesivas partes literales del propio Lemierre. Celebra más sus aportaciones a la teoría artística dieciochesca con las traducciones de la obra de Alberti y Leonardo que su labor poética ${ }^{20}$. La peor de las valoraciones ejercidas sobre la obra de Rejón por parte de Menéndez Pelayo fue la actitud de mero copista de otros autores franceses, desprestigiando la faceta innovadora del autor a la hora de recuperar la plasmación de ideas artísticas en versos didácticos.

La recuperación y puesta en valor del ideario de Rejón tuvo que superar el lapidario testimonio de Menéndez Pelayo y esperar hasta ya bien avanzado el siglo xx. En 1975 en la Historia de la crítica de Arte en España de Juan Antonio Gaya Nuño hallamos una breve cita a la aportación teórica del siglo XVIII por Rejón de Silva: "En 1786 publicó en Segovia La Pintura. Poema didáctico en tres cantos, de pobre inspiración, plagado de lugares comunes, y, según Menéndez Pelayo, plagio

19. XaVIER DE FELler, François. Dictionnaire Historique des Hommes qui se sont fait un nom par leur génie, leurs talents, leurs erreurs ou leurs crimes. Eds. C.-I. Busson y C. Weiss. Paris: J. Leroux, Jouby et Ce libraires - Gaume Freres Libraires, 1850, vol. VI, p. 197.

20. Menéndez Pelayo, Marcelino. Historia de las ideas estéticas en España. Madrid: Consejo Superior de Investigaciones Científicas, 1994, vol. I, pp. 1523-1525. 
a veces del francés Lemierre» ${ }^{21}$. Francisco José León Tello y María M. Virginia Sanz Sanz en su trabajo conjunto Tratados neoclásicos españoles de pintura y escultura enfocan su criterio desde una óptica más objetiva. El estudio analiza todos los planteamientos teóricos abordados por el autor tanto en su diccionario como en el poema. Presentan de manera pormenorizada los temas principales que aparecen en el "tratado en verso", generando una visión global de los intereses teóricos y estéticos del personaje ${ }^{22}$; sin embargo, no llegan a profundizar en las fuentes principales utilizadas por Rejón. Cinco años después, otra de las investigadoras que recuperó las ideas teóricas del autor del poema fue Concepción de la Peña Velasco.

Su labor fue fundamental para que hoy en día podamos valorar la dimensión de la literatura artística de Rejón. Aportó mayor claridad sobre diversos problemas biográficos que surgieron en la recomposición histórica de la trayectoria vital de Rejón, permitiendo desvincular parte de su obra literaria de la de su padre, Diego Rejón de Silva. En sus Aspectos biográficos y literarios de Diego Antonio Rejón de Silva, monografía que sirve de introducción a las reproducciones facsímiles del poema y el diccionario, la autora también analiza la teoría artística expresada en los versos de Rejón ${ }^{23}$. En la línea de la tesis anterior, desmonta la hipótesis de Menéndez Pelayo afirmando cómo Rejón de Silva contrastó con citas y reflejó aquellos poemas didácticos franceses en los que había inspirado su labor. De igual modo, añade otros referentes extranjeros y nacionales que servirían de base al autor. La investigación sobre las ideas artísticas del poema de Rejón de Silva continúa siendo una de las más completas hasta la fecha.

Así, partiendo de la recepción del poema didáctico observamos que la idea general promulgada por críticos y comentaristas fue su fragilidad a nivel de contenidos debido a su composición lírica. Aquellos estudiosos que profundizaron en la lectura completa del texto observaron que, además del valor de la teoría versificada, el poema didáctico disponía de un aparato paratextual que trató de potenciar las carencias sobrevenidas al uso del verso como elemento discursivo.

\section{ESTRUCTURA, PRÓlOGO Y GRABADOS DEL POEMA}

La primera impresión que obtenemos tras un breve análisis de La Pintura es la del carácter educativo que el autor quiso transmitir con su elaboración lírica.

21. Gaya Nuño, Juan Antonio. Historia de la crítica de arte en España. Madrid: Ibérico Europea de Ediciones, 1975 , p. 128.

22. León Tello, Francisco José y SAnz Sanz, María Virginia. Tratados neoclásicos españoles de pintura y escultura. Madrid: Universidad Autónoma, 1980, pp. 325-365.

23. Peña Velasco, Concepción de la. Aspectos biográficos y literarios de Diego Antonio Rejón de Silva. Murcia: Colegio Oficial de Aparejadores y Arquitectos Técnicos, 1985, pp. 67-86. Hoy en día el texto original de 1786 se puede consultar digitalizado en diferentes repositorios bibliográficos electrónicos. https://bibliotecadigital.jcyl.es/i18n/consulta/resultados_ocr.cmd?buscar_cabecera=Buscar\&tipo =elem\&id=1887\&tipoResultados=BIB\&posicion=2\&forma=ficha (Consultado el 09/05/2020). 
Editada e impresa en Segovia en el año 1786 por Antonio Espinosa de los Monteros, la obra se enmarcó en la dinámica ilustrada de poetizar sobre la ciencia y el arte que tan fecunda producción tuvo durante toda la centuria ${ }^{24}$. En España se redactaron otros poemas didácticos dedicados a diversas materias como el ya citado La Música de Iriarte e incluso a temas con menores posibilidades líricas, sobre todo a las ciencias naturales: el origen de una tormenta, los cambios climáticos o los recientes avances científicos tuvieron acogida en aquellos trabajos versificados - cuya calidad poética fue sometida al mayor interés de sus creadores por glosar su erudición en verso- denominados poemas didácticos o también llamados poemas filosóficos ${ }^{25}$.

Previo al análisis del texto es preciso puntualizar algunos de los aspectos generales. La métrica utilizada para la composición del poema es la silva, formato que le otorga gran libertad de creación y mejor capacidad de exposición para su trabajo, aunque no lo hará con el uso dado por los autores clásicos ${ }^{26}$. Del mismo modo, la rima elegida por el autor es la consonante. Con ello se agiliza la lectura y se dan más facilidades para la memorización, en cierto modo recordando la labor mnemotécnica que en su día tuvieron los versos didácticos en la tratadística medieval y renacentista ${ }^{27}$. Nada tiene que ver el tratamiento de la silva que realizó Rejón de Silva con sus predecesores del Siglo de Oro. Una circunstancia totalmente comprensible, ya que el autor justifica al inicio de su tratado su falta de espíritu poético, dado que ello no es el tema principal de su poema. La Pintura se genera expresamente para glorificar las excelencias de la pintura y procura ser una

24. Antonio Espinosa de los Monteros, pese a que fue más conocido por su labor de grabador, mantuvo ejercicio de impresor en Segovia entre 1781 y 1800, iniciando una experiencia similar en Madrid cerca del año 1786. Tras su muerte en 1812 la imprenta pasa a manos de su hijo, José Espinosa. Véase Reyes Gómez, Fermín de los. «El impresor Antonio Espinosa de los Monteros en Madrid: avance para su estudio». Revista General de Información y Documentación, 2004, 14, pp. 121-125. BÉNÉZIT, Emmanuel. Dictionnaire des peintres, sculpteurs, dessinateurs et graveurs. Paris: Gründ, 1999, vol. V, p. 188.

25. ARCE, Joaquín. La poesía del siglo ilustrado. Madrid: Editorial Alhambra, 1985, p. 20; CEBRIÁN, José. "Poesía didáctica y ciencia experimental en la Ilustración española». Bulletin Hispanique, 1996, 98, pp. 121-125; LORENZO Álvarez, Elena de. Nuevos mundos poéticos: la poesía filosófica de la Ilustración. Oviedo: Universidad de Oviedo-Instituto Feijoo de Estudios del siglo XVIII, 2002; CARNERO ARBAT, Guillermo. "Por la emoción a la idea: la poesía filosófica del siglo XVIII". En EGIDO, Aurora y LAPLANA GIL, Enrique (coords.). La luz de la razón: literatura y cultura del siglo XVIII. A la memoria de Ernest Lluch. Zaragoza: Instituto Fernando el Católico, 2010, pp. 121-132.

26. BAEHR, Rudolf. Manual de versificación española. Eds. Klaus Wagner y Francisco López Estrada. Madrid: Gredos, 1973, pp. 378-380.

27. Iriarte en los prolegómenos de su poema explica la necesidad de la rima consonante en las composiciones didácticas: "Determiné usar verso de consonante: lo primero, porque, si un Poeta didáctico se toma el trabajo de poner los preceptos en verso, es para que se queden impresos en la memoria de quien los lee». Iriarte, Tomás de. La Música. Poema. Madrid: Imprenta Real, 1789, prólogo, s/n. Rejón, además de conocer la obra de Iriarte, poseía un volumen de la obra en su biblioteca particular. PeÑa Velasco. Aspectos biográficos, op. cit., p. 70. 


\section{幽 \\ LA PINTURA}

POEMA DIDACTICO EN TRES CANTOS.

POR

Don Diego Antonio Rejon de Silva, del Consejo de S. M. su Secretario, Oficial de la

Primera Secretaría de Estado y del Despacho; de la Real Academia de las Artes.

Si no es Națuraleza la Pintura, es tan semejante á ella, que en sus obras se engaña la vista, y ha menester valerse del tačto para reconocellas. Don Diego Saavedra, Empresa II.

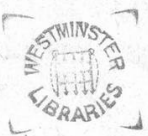

CON LICENCIA:

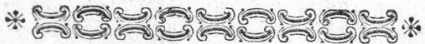

En Segovia: Por Don Antonio Espinosa de los Monteros. Año de 1786 .

Fig. 5. Diego Antonio Rejón de Silva. La Pintura: poema didáctico en tres cantos. Segovia: Imprenta de Antonio Espinosa de los Monteros, 1786, portada. Fuente: Biblioteca Digital de Castilla y León.

perfecta síntesis de las técnicas, doctrinas y enseñanzas para su correcta práctica. Con su texto nos muestra sus ideas artísticas y las fuentes donde se ha sumergido para construir su conocimiento sobre el arte pictórico. Aunque se muestra fuertemente dependiente de las ideas propias del primigenio sistema académico español y de los referentes intelectuales de su época, supo mostrar en sus versos una opinión propia sobre la teoría artística. 
Antes de evaluar otros elementos, hemos de subrayar debidamente la cita que expone el autor en el frontis de la obra: "Si no es Naturaleza la Pintura, es tan semejante á ella, que en sus obras se engaña la vista, y ha menester valerse del tacto para reconocellas». Una llamada de autoridad extraída de las Empresas políticas del murciano Diego Saavedra Fajardo, en concreto la empresa II. La cita rememora el desarrollo de una empresa destinada a la educación de futuros gobernantes y príncipes. Destacaremos dos elementos concretos del emblema elegido por Rejón para la portada de su obra. Por un lado, el uso del arte de la pintura ligado a las ideas de formación y educación. El lienzo en blanco que aparece representado equivale a la mente del joven que inicia su aprendizaje; la tabula rasa que se ha de ver configurada de una correcta educación: ad omnia (para todo). El valor de un correcto sistema formativo se presenta fundamental en el siglo XVIII, siendo uno de los principales motores por los que apuestan los ilustrados a la hora de transformar la sociedad en la que viven. Saavedra Fajardo destaca a lo largo de su emblema que "la enseñanza mejora a los buenos, y hace buenos a los malos» 28

Una reflexión que Rejón quiso desarrollar después de afincarse en Murcia. Tras su llegada de la Corte y ya inmerso en los círculos aristocráticos murcianos insiste en la idea de generar escuelas dirigidas a los sectores más desfavorecidos. Como representante de la Real Sociedad Económica de Amigos del País de Murcia propuso al Concejo de la ciudad la creación de escuelas en los centros parroquiales. Ello permitiría asentar las bases de una mínima educación en los hijos de pobres y huérfanos, cuestión que a la larga sería beneficiosa para toda la población ${ }^{29}$. Por otra parte, esa enseñanza debía verse reforzada con una sólida formación en disciplinas artísticas. A lo largo de la explicación del emblema se insiste en la importancia de la contemplación de lienzos, estatuas o grabados, que no han de faltar en una buena formación cultural. Todo este discurso inicial nos plantea la dependencia que pudo existir por parte del autor con las ideas artísticas de Saavedra Fajardo, reflejadas en la estructura del poema. De hecho, en el manuscrito del poema que se conserva en la Biblioteca Nacional de Madrid (mss. 4406), la cita que aparece en la portada también pertenece a Saavedra Fajardo, pero no corresponde con la publicada en la versión impresa. Concretamente pertenece a la República Literaria (1655): «Arte emula de la naturaleza y remedo de la obra de Dios ${ }^{30}$.

28. SaAvedra Fajardo, Diego. Empresas políticas. Ed. Sagrario López. Madrid: Cátedra, 1999, p. 205.

29. Peña Velasco. Aspectos biográficos, op. cit., p. 31.

30. La importancia en el uso de la imagen con capacidades didácticas y, a su vez, configuradora de la mentalidad de un aprendiz se halla inmersa a lo largo de los versos de Rejón de Silva, en cierto modo deudora de las reflexiones que ya había publicado Saavedra Fajardo. CHECA CREMADEs, Fernando y Morán Turina, José Miguel. "Las ideas artísticas de Diego de Saavedra Fajardo». Goya: Revista de Arte, 1981, 161-162, p. 325. 
Continuando con el análisis preliminar ahora nos centraremos en el prólogo que antecede al poema. Sus primeras líneas van dedicadas a recordar el estado de la poesía didascálica sobre temas pictóricos en el reino español afirmando que «únicamente se encuentra un Poema de la Pintura, que escribió el Lic. Pablo de Céspedes ${ }^{31}$. Omite las breves octavas reales de José García Hidalgo presentes en sus Principios para estudiar el nobilisimo arte de la pintura y más construcciones poéticas anteriores en las que la teoría de la pintura tuvo acogida desde una óptica doctrinal ${ }^{32}$. De igual modo, el mismo año que se editó el poema de Diego Antonio Rejón de Silva vieron la luz las Conversaciones sobre la escultura de Celedonio Nicolás de Arce y Cacho, en cuya conversación III hallamos un elogio sobre la escultura compuesto en verso ${ }^{33}$. Aunque reconoce la existencia de aquellas loas líricas auriseculares, lamenta la falta de poetas que se hayan atrevido a preparar en un formato didáctico los preceptos pictóricos con un estilo elegante. Igualmente, se une a todo lo anterior lo prolífico que fue el género de la poesía didáctica sobre las artes en otros países europeos: Italia, Inglaterra, Holanda y, de manera especial, en Francia, por citar algunos casos. Un orgullo patrio que le hizo iniciarse en la misión de cantar las loas de la pintura y sus preceptos de igual manera que se estaba haciendo en el continente.

Pese a que sabe y admite sus limitaciones en cuanto al arte de la versificación, deseó compensar al lector con su erudición sobre la teoría de la pintura, participando desde la posición de aficionado en el enriquecimiento del gusto nacional ${ }^{34}$. La idea de aprendizaje propuesta nos recuerda a la expuesta por los anteriores tratadistas del Siglo de Oro y también a los ideales del sistema académico: el aprendiz ha de ir superando los avatares de la enseñanza de forma progresiva y en ascenso hacia la perfección y buen manejo del arte de la pintura ${ }^{35}$. Así, el poema

31. Rejón de Silva, Diego Antonio. La Pintura: Poema didáctico en tres cantos. Segovia: Imprenta de D. Antonio Espinosa de los Monteros, 1786, prólogo, s/n.

32. EgIDO, Aurora. Fronteras de la poesía en el Barroco. Barcelona: Crítica, 1990, pp. 164-197; CALVO SERRALlER, Francisco. "El pincel y la palabra: una hermandad singular en el barroco español». En PORTús PÉrez, Javier (ed.). El Siglo de Oro de la pintura española. Madrid: Biblioteca Mondadori, 1991, pp. 187-203, y PORTús PÉrez, Javier. Pintura y pensamiento en la España de Lope de Vega. Guipúzcoa: Nerea, 1999, pp. 31-41.

33. ARCE Y CACHO, Celedonio de. Conversaciones sobre la escultura. Intr. Cristóbal Belda Navarro. Madrid: Consejo General de la Arquitectura Técnica de España, 1996, pp. XVII-XVIII y 28-41.

34. Úbeda de los Cobos. Pensamiento artístico..., op. cit., p. 104.

35. Pablo de Céspedes expone en una de sus octavas reales este duro camino que descrito por su lírica es: «Un día y otro día, y el contino / Trabajo hace prático y despierto; / Y después que tendrás seguro el tino / Con el estilo firme y el pulso cierto / No cures atajar luengo camino, / Ni por allí te engañe cerca el puerto: / Vedan que el deseado fin consigas / Pereza y confianzas enemigas». Rubio lapaz, Jesús y Moreno Cuadro, Fernando. Escritos de Pablo de Céspedes. Córdoba: Diputación de Córdoba, 1998, p. 378. Idea que retoman en sus diferentes tratados Pacheco, Carducho, Jusepe Martínez y todos los tratadistas modernos, influenciados por las máximas de Leonardo, Alberti, Vasari o Lomazzo. Asimismo, Palomino en su Museo Pictórico y Escala Óptica configura su obra en capítulos que representan el estado del discípulo en el momento en el que se ha de enfrentar con una cuestión 
se divide en tres cantos equivalentes a las tres unidades de la pintura reconocidas por Rejón de Silva: el dibujo, la composición y el colorido. El orden elegido por el autor para la exposición de los temas no es una cuestión baladí, puesto que responde al valor que otorga a dichas partes. Para él, al igual que para la teoría artística dieciochesca y el ámbito académico, el dibujo ha de primar por encima de todas las partes, siendo circunstancia indispensable en la confección de una bella pintura. Un pensamiento que quedó suficientemente justificado en las fuentes teóricas utilizadas para la confección del poema ${ }^{36}$.

Tal y como hemos señalado con anterioridad, el autor fue consciente de que el medio escogido para la exposición de sus ideas artísticas limitaba su extensión. Es por ello por lo que Rejón se enorgullece de haber realizado su obra acudiendo a las reflexiones de grandes eruditos de la tratadística española y extranjera, recogiendo estas ideas en sus anotaciones finales. Pacheco, Carducho y Palomino son los tres grandes teóricos españoles en los que afirma asentarse; del primero añade que su tratado podría valorarse a modo de gran síntesis de las ideas de Alberti y Leonardo. Es interesante, asimismo, el comentario sobre el uso que hace de otros poemas didácticos - desarticulando la teoría del plagio flagrante-, en especial del de Watelet ${ }^{37}$. Igualmente, y aunque no lo menciona de forma directa, Rejón de Silva tuvo una especial predilección tanto por los ejemplos pictóricos como por los razonamientos teóricos del caballero filósofo Anton Raphael Mengs. En este sentido, podemos extraer la conclusión de que los principales referentes teóricos de Rejón de Silva serían los tratadistas renacentistas, los representantes de la tradición teórica española barroca y algunos de sus contemporáneos, por lo que sienta sus raíces en un ideario ecléctico dividido entre la innovación neoclásica y la tradición barroca del siglo XVII y comienzos del XVIII ${ }^{38}$.

concreta de la pintura, comenzando el libro I "el aficionado" hasta el libro IX, "el perfecto», simulando ese ascenso hacia el grado de la perfección práctica y teórica.

36. Desde los tratadistas renacentistas italianos hasta los teóricos españoles del Barroco, son constantes los argumentos en favor de la primacía del dibujo que Rejón de Silva asimiló y versificó. La definición de la voz "Dibujo» en su Diccionario también es clara: "Parte principal de la Pintura y Escultura, que enseña la arreglada distribución, contorno y simetría de las partes de un cuerpo en su justa proporción [...] El Dibuxo es el ingreso único e indispensable en la práctica de esta facultad». REJÓN DE SILva, Diego Antonio. Diccionario de las nobles artes para instrucción de los aficionados, y uso de los profesores. Segovia: Imprenta de D. Antonio de Espinosa, 1788, p. 81.

37. Del poema de Watelet traduce en una nota aparte toda la información teórica referente a la representación pictórica de las expresiones. REJÓN DE SILVA. La Pintura..., op. cit., pp. 108-116.

38. Henares CuÉlLar, Ignacio. La teoría de las artes plásticas en España en la segunda mitad del siglo XVIII. Granada: Secretariado de Publicaciones de la Universidad, 1977, pp. 91-92. 


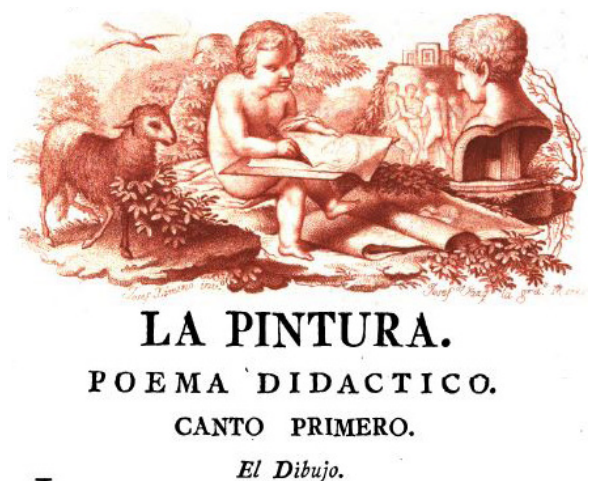

Fig. 6. José Vázquez y José Ximeno. Alegoría del dibujo, grabado calcográfico estampado en tinta bistre. En La Pintura: poema didáctico en tres cantos.

Segovia: Imprenta de Antonio Espinosa de los Monteros, 1786, p. 1.

Fuente: Biblioteca Digital de Castilla y León.

Complementando los elementos paratextuales del poema didáctico, al inicio de cada canto se hallan unos grabados alegóricos que refuerzan la unión de texto e imagen, motivando una visión intelectual del arte pictórico. Rejón de Silva se preocupó personalmente de la invención de dichas imágenes simbólicas; por medio de estos emblemas se pretendió sintetizar los principales atributos y virtudes que confeccionan las diferentes secciones del arte pictórico que iban a ser interpretadas en los cantos, ejerciendo de síntesis visual de los posteriores versos. De este modo, en el primero de ellos encontramos un pequeño niño o genio en un entorno campestre e idílico, preparado para dibujar un busto propio de la Antigüedad clásica.

A su lado, surgiendo de la floresta, aparece un cabritillo y encima de aquel un pájaro. En el fondo de la composición puede distinguirse un grupo de figuras humanas en actitudes diversas y mostrando diferentes escorzos. Justo encima de ellas, en un pequeño promontorio, se alzan tres piezas arquitectónicas, quizá rememorando ejemplos de la arquitectura clásica. El pequeño grabado nos habla de la labor fundamental que ha de emprender el joven pintor: el constante ensayo y práctica del dibujo, utilizando el natural y la belleza clásica. El simbolismo del cordero puede tener varias explicaciones, sobre todo desde una óptica cristiana, aunque en el ámbito artístico que se encuentra nos decantamos por una velada alusión al origen de la copia del natural que en sus inicios practicó el pintor italiano Giotto di Bondone y que recogen Lorenzo Ghiberti en sus Comentarii y Giorgio Vasari en Le vite de' più eccellenti pittori, scultori e architettori ${ }^{39}$. De igual

39. "A la edad de diez años, Bondone, le confió el cuidado de un rebaño de ovejas que él llevaba a pastar diariamente por distintos lugares. Tenía una inclinación innata por el dibujo, lo que a 
modo, el pequeño pájaro que sobrevuela el cordero puede ser una referencia a aquellas representaciones tan celebradas de la Antigüedad realizadas por el pintor griego Zeuxis, cuyas uvas pintadas se acercaron tanto al natural que engañaron a las propias aves. Una leyenda clásica que fue recuperada reiteradamente por la literatura artística posterior ${ }^{40}$. La siguiente alegoría hace mención al tema de la composición. En el dibujo vemos a otro genio o mancebo acomodado sobre una roca.

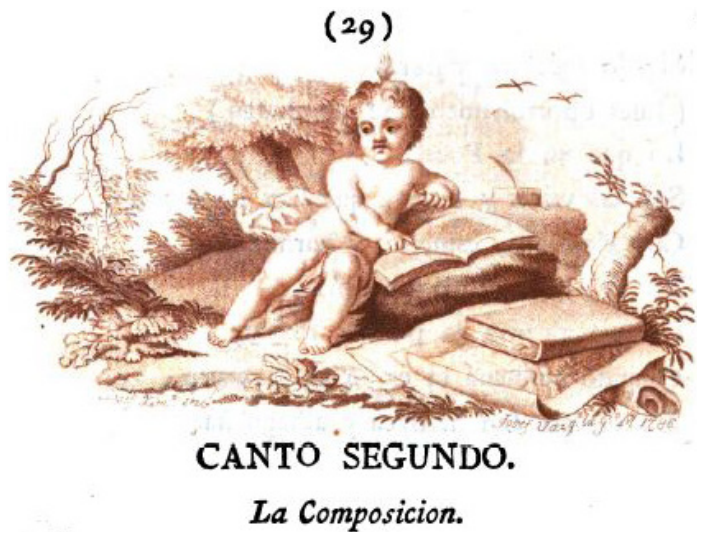

Fig. 7. José Vázquez y José Ximeno. Alegoría de la composición, grabado calcográfico estampado en tinta bistre. En La Pintura: poema didáctico en tres cantos. Segovia: Imprenta de Antonio Espinosa de los Monteros, 1786, p. 29. Fuente: Biblioteca Digital de Castilla y León.

Cerca de la figura distinguimos una especie de tintero del que sobresale una pluma. Mantiene apoyado a su lado un libro abierto, al que señala con un dedo mientras aparta la vista hacia otra parte de la escena. Agrupados al lado de la figura distinguimos unos libros y pliegos. Nos recuerdan posibles colecciones de estampas y grabados que el joven genio tiene preparados para consultar; estas imágenes impresas señalan la necesidad del joven pintor de autogenerarse una cultura visual. Para ello ha de consultar materiales gráficos de calidad inspirados en los mejores ejemplos de los maestros y de obras artísticas de renombre representativas de los gustos estéticos imperantes en el territorio europeo. Mediante el

menudo le llevaba a representar por placer figuras del natural o de su imaginación sobre piedras, tierra o arena. Y sucedió que un día el muy celebrado Cimabue, de viaje por los alrededores de Florencia (ciudad donde era muy apreciado), vio en Vespignano a Giotto, que, mientras sus ovejas pastaban, retrataba a una de ellas sobre una piedra llana y pulida con otra apuntada, sin otro conocimiento para hacerlo que su instinto natural». VASARI, Giorgio. Las Vidas de los más excelentes arquitectos, pintores $y$ escultores italianos desde Cimabue a nuestros tiempos. Eds. Luciano Bellosi y Aldo Rossi. Madrid: Cátedra, 2014, pp. 116-117.

40. Plinio. Textos de Historia del Arte. Ed. Esperanza Torrego. Madrid: Visor, 1987, p. 93. 
uso -no el abuso, pues generaría vicios innecesarios- de ellos se le facilitará el ejercicio de las composiciones en sus diversos trabajos. Por último, el canto dedicado al colorido se halla encabezado por un grabado similar a los anteriores. Hallamos al mismo genio inmerso en el espacio idílico de las anteriores figuraciones.

Se encuentra rodeado por la naturaleza; sostiene con su mano derecha una lira y con la izquierda una paleta y pincel. El genio se dispone sentado sobre un caballete en el que descansa un lienzo y donde se puede apreciar una composición. En dicha escena, a su vez, se representan dos figuras humanas. La idea principal que sugiere al espectador es la del hermanamiento de las artes de la pintura y la poesía, el clásico tópico horaciano del ut pictura poesis. La lira, instrumento asociado al dios Apolo, termina asimilándose como un símbolo más de la alegoría de la poesía ${ }^{41}$. El genio hace gala y dominio de las dos, exhibiéndolos a un nivel similar en ambas manos; no obstante, si concretásemos más aún, podríamos buscar una mención a las relaciones entre música y colorido que Rejón de Silva desarrollará en sus versos y ampliará en el discurso prosaico de las notas finales.

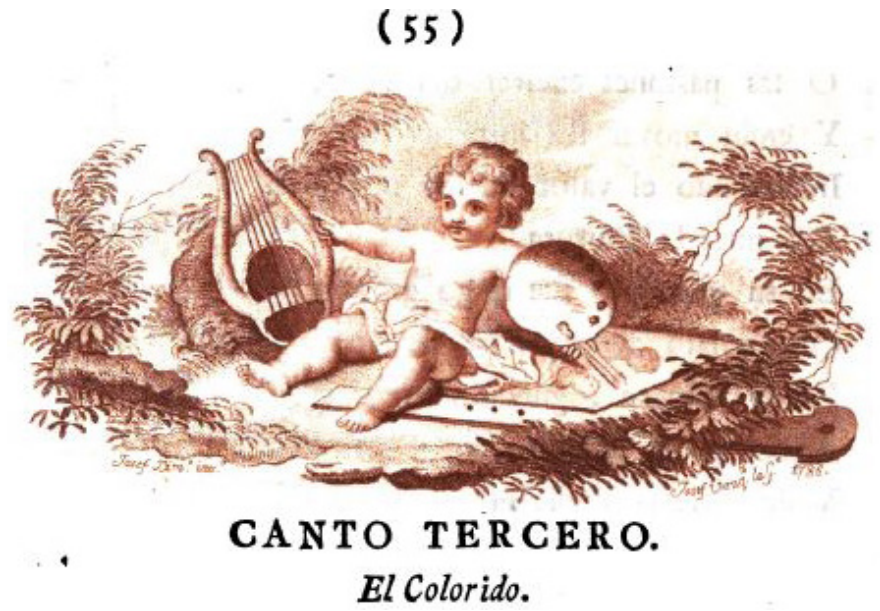

Fig. 8. José Vázquez y José Ximeno. Alegoría del colorido, grabado calcográfico estampado en tinta bistre. En La Pintura: poema didáctico en tres cantos. Segovia: Imprenta de Antonio Espinosa de los Monteros, 1786, p. 55. Fuente: Biblioteca Digital de Castilla y León.

41. Tervarent, Guy de. Atributos y símbolos en el arte profano. Diccionario de un lenguaje perdido. Ed. José María Sousa Jiménez. Barcelona: Ediciones del Serbal, 2002, pp. 338-339. 


\section{NOTAS ACLARATORIAS AL FINAL DEL POEMA}

Junto a todo el material previo y los grabados inmersos en el poema hemos de subrayar el papel de las notas adjuntas al final de la obra. Ejerciendo de explicaciones prosaicas de aquellas partes que Rejón de Silva comprende sintetizar en demasía, añaden mayor erudición a los versos y precisan el ideario artístico del autor explicitado a lo largo del poema. Al igual que otros escritores ilustrados, el vasto caudal de información que dominan y el gran deseo de plasmar toda su erudición hicieron harto complicado que el espacio textual del que disponían pudiese acoger toda la información manejada. Buen ejemplo de ello son los propios trabajos anteriores de Rejón en la edición de los tratados de Alberti y Leonardo, donde se incluyen algunas notas más a las que ya contenían los originales. Igualmente, en su propuesta de traducción del clásico texto de Winckelmann, Historia del arte entre los antiguos, que quedó manuscrito y fue legado por la viuda de Rejón a la Academia de San Fernando, también insertó notas sobre conceptos e ideas del arte de la Antigüedad, tanto en el prólogo como en las partes finales ${ }^{42}$.

Retomando el caso concreto del poema, la variedad informativa de las notas, aunque acorde con el contenido al que refieren, las convierten en glosas de gran interés por sí mismas: datos históricos sobre la situación de obras de arte; precisiones biográficas de artistas; noticias sobre modelos escultóricos clásicos para la imitación y práctica de los aprendices; explicaciones sobre el correcto desempeño de la práctica pictórica adecuadas a los conceptos de Mengs; citas y traducciones de otros tratados artísticos como el poema didáctico de Claude-Henry Watelet L'art de peindre, poëme (1760) o el tratado del abate Du Bos, Réflexions critiques sur la poésie et sur la peinture (1719).

De especial interés son las notas vinculadas a los versos más nostálgicos y apologéticos elaborados por Rejón de Silva. Con ellos construye una de las grandes aportaciones al debate teórico de su tiempo: la postura elogiosa y reivindicativa hacia la pintura española del Siglo de Oro $^{43}$. La revalorización de los grandes pinceles españoles del Seiscientos desde la óptica de un ilustrado de mediados del siglo XVIII añade mayor valor al posicionamiento; el contexto cultural en el que fue escrita su defensa de la pintura del Siglo de Oro era de cierta hostilidad, puesto que la historiografía europea no había prestado la debida atención a encajar en un discurso artístico la escuela española ${ }^{44}$. El posicionamiento de Mengs acerca de

42. En este caso concreto el aparato crítico desarrollado por Rejón de Silva se halla apenas esbozado debido a que no llegó a finalizarlo. Winckelmann, Johann Joachim. Historia de las artes entre los antiguos. Ed. Alejandro Martínez Pérez. Madrid: Real Academia de Bellas Artes de San Fernando, 2014, pp. 459-460.

43. Recientemente, Peña Velasco ha estudiado esta circunstancia en el poema de Rejón de Silva. PeÑa Velasco, Concepción de la. «Rejón de Silva y el discurso ilustrado sobre la escuela de pintura española». Atrio, 2013, 19, pp. 69-82.

44. García Felguera, María de los Santos. Viajeros, eruditos y artistas. Los europeos ante la pintura española del Siglo de Oro. Madrid: Alianza, 1991, pp. 19-21, y ÚBEDA DE LOs CoBos, Andrés. 
la escuela española, remodelado por Nicolás de Azara en su edición de los textos del artista sajón, tampoco lo posiciona a favor ${ }^{45}$. Es más, las reflexiones sobre el arte hispano fueron ejecutadas para reprender el excesivo apego por la imitación del natural y la falta de seguimiento de la Antigüedad clásica, alejándose de los cánones de belleza ${ }^{46}$. Se salvan de esta condicionada criba del pintor-filósofo tres grandes artistas hispanos: Velázquez, Ribera y Murillo ${ }^{47}$.

Rejón, pese a que tiene un claro arquetipo en el Mengs teórico y práctico, no refrendó las ideas sobre la pintura española que promulgaba el intransigente espíritu neoclasicista de Azara. La principal virtud que observó en la obra de sus antecesores no fue el dominio del bello ideal que tanto ansiaban encontrar los estetas dieciochescos ${ }^{48}$. La virtud y el placer visual que encierran las obras de los pintores auriseculares, según el autor del poema, se encuentra en su acercamiento a la verdad con la que representaban los objetos y personas, a esa denostada representación de la realidad ${ }^{49}$. Así, utiliza el denostado naturalismo de los pintores del Siglo de Oro como un argumento a favor de ellos, circunstancia que para la crítica era un punto de desprestigio ${ }^{50}$. En este sentido, los elogios dirigidos por Rejón en las aclaraciones finales a la figura de Murillo son verdaderamente clarificadores, situándolo en el mismo escalafón de los grandes paradigmas del arte italiano y francés de la Modernidad. Empero, la fragilidad de la propaganda y difusión del arte hispano no propiciaba la

"La Prehistoria de la Historia del Arte». En Historiografia del Arte Español en los siglos XIX y XX. Madrid: Alpuerto, 1995, pp. 128-130.

45. La controversia que generó la traducción y edición de la obra de Mengs mantuvo un debate arduo a mediados del siglo XviII entre personalidades de la talla de Tomás de Iriarte, Gaspar Melchor de Jovellanos o Antonio Ponz. Para un análisis más específico véase el estudio introductorio a la edición facsímil elaborado por Mercedes Águeda. Mengs, Antonio Rafael. Obras de D. Antonio Rafael Mengs. Publicadas por don Josep Nicolás de Azara. Madrid: Dirección General de Bellas Artes y Archivos, 1989, pp. 14-16.

46. El inicio de la búsqueda de la belleza pictórica lo encuentra Mengs en las labores de patronazgo ejercidas por Carlos I y Felipe II, cuyo interés por las bellas artes permitió emerger a España del letargo artístico en el que se hallaba sumida. Aunque el problema viene en el arquetipo que se quiso utilizar: «El amor de las artes se quedó concentrado en sus personas, sin comunicarse a la nobleza, que continuó pensando como hasta entonces en las armas y en las riquezas. Puso además de eso el Escorial en un desierto; y así no podía ser observado más que de pocos: y por fin tuvo la desgracia de que cuando los españoles comenzaron a cultivar las artes, yéndolas a buscar y a aprender a Italia, ya habían empezado estas a decaer del buen Gusto en aquel Pais; y así los españoles que las traxeron a estos Reynos, traxeron consigo un gusto viciado». Ibid., p. 186.

47. «Pero quánta diferencia hay entre ellos! ¡Quánta verdad é inteligencia de clarobscuro no se observa en los quadros de Velázquez! ¡Cómo entendió bien el efecto que hace el ayre interpuesto entre los objetos, para hacerlos comparecer distantes los unos de los otros!». Ibid., pp. 221-222.

48. Ibid., p. 266, y ÚBedA DE LOS CoBos. Pensamiento artístico..., pp. 247-255.

49. Dentro de esta parte de la nota añadirá una subnota para especificar este contenido: «Si el fin del Pintor es imitar la Naturaleza, mírense las obras de la Escuela Española, y véase si el nombre de Naturalistas es censura o elogio». ReJón de Silva. La Pintura..., op. cit., pp. 93-94.

50. Gállego SERRANo, Julián. Visión y simbolos en la pintura española del Siglo de Oro. Madrid: Cátedra, 1984, pp. 270-271. 
implantación de nuestro arte fuera de la península. Para ello se presentó necesaria la labor de burilistas que copiasen las obras maestras del arte español y, con ello, dieran noticia de sus magnificencias por los distintos rincones de Europa. Con estas palabras lo transmite el autor:

Para prueba de esto, aunque pudiéramos citar muchos de aquellos, que acreditan de gran á un Pintor, hechos por mano de Profesores Españoles; basta que hagamos mención por ahora de las excelentes obras que executo Ribera, Velazquez, y el célebre Murillo en su mejor tiempo para la Iglesia de la Caridad de Sevilla, y otros varios templos, obras tan dignas de ser admiradas por todas partes, como desgraciadas en no haber tenido un Audran que pudiera con la destreza de su buril haberlas multiplicado por Europa; que entonces al hablar de los Pintores sublimes de cada Nacion en las historias, ocuparía indubitablemente nuestro Murillo en España el mismo lugar que obtienen en sus respectivos países Pusino, Le-Brun, Corregio, Pablo Verones, Ticiano, Caraci, y aun el sin igual Rafael de Urbino, pues es evidente que en quanto á la expresión muchas veces no hizo mas el Profesor Italiano, que el español, quedando éste siempre superior en la belleza, frescura y naturalidad del colorido $^{51}$.

La actividad de los grabadores serviría para paliar el desconocimiento del arte español, y en especial de su pintura, fuera de nuestras fronteras. Una demanda que se recuperó durante el Setecientos, pero ya había surgido en las reclamaciones de algunos tratadistas de los siglos XVI y XVII, quejándose de lo minoritaria que era su práctica, en muchas ocasiones favorecida por artistas extranjeros ${ }^{52}$.

Aunque Rejón despliega una gran madurez y un posicionamiento crítico innovador sobre la pintura española, en otros aspectos se manifiesta anclado a la tradición teórica hispana contrarreformista que le precede. En algunos momentos del poema hace gala de una actitud ortodoxa sobre el uso de las imágenes religiosas, lo que le llevó a justificar mediante las notas finales el decoro que debían presentar los artífices. Una actitud que, curiosamente, llegó a reprochar en sus comentarios acerca de la obra de Palomino ${ }^{53}$. En los versos y, con mayor profusión, en el apéndice final de notas se manifiesta la necesidad del correcto uso de la iconografía cristiana en la creación de imágenes pictóricas. Es por ello por lo que cuando el autor nos remite a la nota dedicada a los versos "de la humana figura cualquier parte», incluidos en una estrofa del primer canto, incluyó el siguiente comentario a propósito de la representación de la imagen de Cristo:

51. Rejón de Silva. La Pintura..., op. cit., p. 95. Sobre la importancia de las pinturas de Murillo en la iglesia de la Caridad de Sevilla y algunos de sus comentaristas durante el siglo xviII véase Navarrete Prieto, Benito. Murillo y las metáforas de la imagen. Madrid: Cátedra, 2017, pp. 247-251.

52. Gallego Gallego, Antonio. Historia del grabado en España. Madrid: Cátedra, 1979, pp. 136-138, y PeÑa Velasco. "Rejón de Silva y el discurso..., op. cit., pp. 70-71.

53. Úbeda de los Cobos. Pensamiento artístico..., op. cit., pp. 58-59. 
En los asuntos divinos es otra cosa. La imagen de Jesu-Christo, como que es Persona Divina, es preciso que tenga una belleza ideál suma; y aun quando se le represente afeado con las ignominias y tomentos que padeció, siempre han de manifestar sus formas aquella elegancia y aquella perfeccion convenientes á un cuerpo, depósito de un Alma bienaventurada, en quien residia toda la Divinidad ${ }^{54}$.

Rejón de Silva aprueba aquí la confirmación de unas ideas aprobadas casi un siglo y medio antes de su obra y que para él siguen contando con total validez. Se posiciona en la línea de la literatura artística del siglo XVI y XVII, y, si quisiéramos precisar algo más, con las reflexiones del padre Juan Interián de Ayala ${ }^{55}$. La belleza idealizada de la Virgen María o del rostro de Cristo fueron temas de gran importancia entre los teóricos del arte del Siglo de Oro: Pacheco, Carducho, Jusepe Martínez y, como colofón de estas ideas barrocas, el propio Palomino. La aportación de Rejón de Silva, pese a hallarse próxima a las nuevas tendencias finiseculares y prerrománticas que comenzaban a aflorar en la España intelectual de Jovellanos, Ceán Bermúdez o Bosarte, entre otros grandes eruditos, no puede deslindarse de la tradición teórica del decoro religioso ${ }^{56}$.

Igualmente, en las notas observamos referencias matemáticas y científicas que, por las particularidades que presentan a la hora de ser explicadas, fueron incluidas fuera de los versos ${ }^{57}$. El Siglo de las Luces profundizó en el vínculo del mundo de las artes y las ciencias, una aspiración deseada por los académicos de las tres nobles artes con el fin de dar un mayor carácter de especialización a sus disciplinas $^{58}$. Bajo el anticuado trasfondo de las consideraciones de liberalidad e

54. Rejón de Silva. La Pintura..., op. cit., p. 91.

55. INTERIÁN DE AYAla, Juan. El Pintor Christiano, y erudito, o tratado de los errores que suelen cometerse frecuentemente en pintar, y esculpir las Imágenes Sagradas. Ed. Luis de Durán y de Basteró. Madrid: Joachin Ibarra, 1782, vol. I, p. 267. Sobre el debate de las imágenes religiosas en los siglos XVI y XVII nos acercan al debate teórico los trabajos de MARÍAs, Fernando. El siglo XVI. Gótico y Renacimiento. Madrid: Sílex, 1992, pp. 186-188, y PORTús PÉREZ, Javier. "Tratados de pintura y tratados de imágenes sagradas en el Siglo de Oro". En Riello, José (ed.). Sacar de la sombra lumbre. La teoría de la pintura en el Siglo de Oro (1560-1724). Madrid: Abada Editores, 2012, pp. 21-31.

56. Martínez-Burgos García, Palma. "El decoro. La invención de un concepto y su proyección artística». Espacio, Tiempo y Forma, serie VII Historia del Arte, 1988, 1, pp. 95-97, y PORTús PÉREZ, Javier. "Indecencia, mortificación y modos de ver en la pintura del Siglo de Oro". Espacio, Tiempo y Forma. Serie VII, Historia del Arte, 1995, 8, pp. 55-88.

57. Unas ideas que se presentan fundamentales en la tratadística y teoría de las artes del siglo XVIII, pero cuya versificación suponía serios problemas dado el escaso carácter poético existente en ello. Será el siglo XVIII el momento de auge de los poemas didácticos sobre temas científicos. El poema Termas de Archena (1777) de López de Ayala o el de José de Viera y Clavijo Los aires fijos (1780) son un claro ejemplo de esa revolución de versificar la ciencia: el primero aborda los efectos terapéuticos de las aguas termales y minerales, el segundo se centra en los estudios de aires fijos o gases. CEBRIÁN, José. La Musa del Saber. La poesía didáctica de la Ilustración española. Madrid: Iberoamericana, 2004, pp. 81-144.

58. Selles, Manuel; PeSet, José Luis y Lafuente, Antonio. Carlos III y la ciencia de la Ilustración. Madrid: Alianza, 1988, pp. 42-44. 
ingenuidad de las artes -todavía presentes en el ideario teórico e incluso en la mentalidad social-, en este caso se reflexiona acerca de los avances científicos logrados en el siglo y que pueden ser utilizados para innovar en el arte pictórico actual $^{59}$. La academia ilustrada quiso progresar en aquellas ideas inspirándose en la labor anterior de hombres del Renacimiento de la talla de Leonardo; sin embargo, se hacía indispensable reforzar aquellas teorías clásicas con las investigaciones contemporáneas $^{60}$. Rejón de Silva acude a citas de autoridades antiguas y actuales, ofreciendo un variado espectro de la cuestión. Por ejemplo, lo vemos en el estudio de la teoría de los colores. Utilizó los avances de Isaac Newton en lo concerniente a la refracción de los «rayos refringibles», si bien cita su obra a través de los «Principios de óptica» de Benito Bails, incluidos en el manual Principios de Matemática de la Real Academia de San Fernando (1758) ${ }^{61}$. Las lecciones de más profusión teórica no podían o no se prestaban de manera amena a ser plasmadas mediante el verso, por lo que fueron recogidas a través de notas como la siguiente, en la que se apremia a los jóvenes para que aprendan mediante la pura teoría científica los entresijos, en este caso, de la perspectiva teatral:

En el tomo tercero de los principios de Matemática de Don Benito Bails, pag. 287, se trata con la brevedad que requiere la naturaleza de aquella obra, acerca de esta parte de la perspectiva [...] quisiera yo que los Jóvenes Pintores se aplicasen á la Perspectiva teatral con fundamento, y desterrasen la barbarie, que por lo comun reyna en ella. Para esto pueden estudiar en la Perspectiva de Viviena, otra obra de un jesuita anónimo, intitulada: La Perspectiva práctica, necesaria a los Pintores, Escultores, Arquitectos, etc. impresa en París año 1663, tres tomos en quarto; y en la del P. Pozo, en las quales se trata con extensión la Perspectiva teatral: y tambien Palomino en el segundo tomo habla de ella, y dá varias reglas, que pueden aprovechar mucho al aplicado ${ }^{62}$.

Mientras que en los versos se sugiere de forma lírica la necesidad de ahondar en estos aspectos, la nota correspondiente introduce el material bibliográfico de manera pormenorizada. En este caso concreto, nos remite a los estudios elaborados por los Galli Bibiena, los de un jesuita anónimo del siglo XVII - ¿Jean de Breuil?- y el monumental tratado de Andrea Pozzo. Así, las explicaciones que no logró construir de manera amplia en el cuerpo principal del poema terminan

59. Belda Navarro, Cristóbal. La ingenuidad de las artes en la España del siglo XVIII. Murcia: Real Academia Alfonso X el Sabio, 1993, pp. 43-46 y 71-82.

60. Hormigón BláNQUEZ, Mariano. «Las matemáticas en la Ilustración española: su desarrollo en el reinado de Carlos III». En Fernández Pérez, Joaquín y GonzÁlez Tascón, Ignacio (eds.). Ciencia, técnica y estado en la España ilustrada. Madrid: Secretaría de Estado de Universidades e Investigación, 1990, pp. 265-278.

61. Bails, Benito. Principios de matemática, donde se enseña la especulativa, con su aplicación a la dinámica, bidrodinámica, óptica, astronomía, geografía, gnomónica, arquitectura, perspectiva y al calendario. Madrid: Joaquín Ibarra, 1776, vol. II, pp. 211-216.

62. Rejón de Silva. La Pintura..., op. cit., pp. 130-131. 
siendo desarrolladas en la parte final, aportándonos una información que no hubiese sido posible integrar en los versos o que sería harto complicado versificar. No menos relevante fue el acopio de noticias sobre avances tecnológicos aplicados a la práctica pictórica. Nos sirven, en este caso, las explicaciones acerca del uso de la pintura al pastel, cuya definición no puede realizarse mediante la lírica, y se justifica en las notas finales:

La Pintura á pastel es principalmente para satisfacer el gusto de los aficionados. Los Profesores solo la usan para algun retrato, ó para el estudio de alguna cabeza en que quieren poner mucha atención y diligencia. La facilidad de tener casi todas las tintas y medias tintas, claros y obscuros preparados ya en los clariones (que son unos trozos, ó puntas de color molido con agua, y dexado secar) hace que este género de pintar sea muy cómodo, y al mismo tiempo sumamente difícil executarlo con toda perfeccion; porque las plazas obscuras, y los golpes grandiosos en los trazos y pliegues de un ropaje los hace mas prontamente el pincél al olio, que el clarion al pastél, aun quando se emplee el dedo en extender el color, de cuyo medio se ha de usar parcamente, según los Profesores que se exercitan en esta clase de Pintura con mas delicadeza y gusto. Se han inventado modos de fixar el pastél, pero ninguno llegó al punto de perfeccion necesaria ${ }^{63}$.

Rejón de Silva no divaga sobre el funcionamiento de esta práctica pictórica, sino que fundamenta la definición en una fuente específica y contrastable. De hecho, en esta ocasión justifica la información emitida a partir del artículo elaborado por el Journal Etranger en febrero de 1757, espacio literario que recogió el testimonio del pintor alemán Mrs. Reifstein ${ }^{64}$. Nuevamente se recurre a una autoridad escrita en lengua francesa, puesto que la facilidad para acceder a las noticias en esta lengua no suponía problema alguno para el autor. Con todo este soporte paratextual se reafirma el marco teórico del poema didáctico, procurándole unas bases de conocimiento que lo enriquecen sin interferir de manera directa en el lirismo procurado por Rejón de Silva.

63. Rejón de Silva. La Pintura..., op. cit., pp. 133-134.

64. Mr. ReIfSTEIN. "Sur la Peinture, avec l'expesé d'une nouvelle façon de peindre en Pastel». Journal Etranger, 1757, 50 (febrero), pp. 100-106. Pocos datos podemos aportar sobre este pintor alemán, puesto que es citado en otras publicaciones similares aportándose solamente su nacionalidad y apellido. En la voz "Pastel» del Dictionnaire de Sabatier de Castres y Préfort ya se menciona esta peculiaridad: "Un Peintre Allemand (M. Reifstein) est parvenu à donner de la solidité aux crayons de pastel qui sont naturellement si tendres, \& à peindre d'une nouvelle maniere, qu'il appelle le pastel en cire». SABATIER de CASTRES y BASSIn de PRÉFORT, Antoine. Dictionnaire des origines, decouvertes, inventions et établissements, ou Tableau historique de l'origine et des progrès de tout ce qui a rapport aux sciences et aux arts. Paris: Moutard, 1777, vol. III, pp. 224-226. 


\section{CONCLUSIONES}

En definitiva, si atendemos a lo expuesto hasta el momento, los elementos paratextuales que acompañan al poema permiten una lectura mucho más completa y comprensible del mismo. La búsqueda de un poema didáctico ilustrado en la que no ha de primar el lirismo sino las partes eruditas y formativas pudo lograrse confeccionando todo el aparato crítico que lo refuerza. Con el análisis de los instrumentos formales que siguen a los versos podemos percatarnos de que el poema didáctico de Rejón de Silva, pese a no poseer un lirismo de calidad, aúna una teoría de la pintura densa y pormenorizada. Se nos presenta un trabajo madurado y reflexionado, puesto que cada detalle estuvo pensado para interpretarse dentro de un mismo mensaje: las alabanzas de la pintura y la defensa de un modelo pictórico correcto a seguir; una obra que es deudora de la mentalidad ilustrada, pero que nace de las raíces teóricas más propias del Siglo de Oro español. El autor unificó en sus versos todos los conocimientos artísticos adquiridos desde su posición de aficionado a las artes, haciendo gala de un amplio dominio de la literatura artística pretérita y contemporánea.

Las renovadas corrientes de pensamiento que abogaban por la recuperación del patrimonio pictórico nacional tienen su acogida en el poema e incluso más en las notas finales que lo enriquecen a nivel informativo. Rejón de Silva reivindica una estructura textual clásica apoyada en el antiguo tópico horaciano de las artes hermanas, junto a un aparato paratextual que refuerza la asimilación de todo el contenido de la obra. El prólogo, grabados, anotaciones y citas concretas hacen mucho más comprensible un texto poético elaborado por un aficionado a las artes líricas y figurativas, cuyo formato impide una mayor demostración de erudición. Ofrecemos esta revisión de conjunto con la cual subrayamos el nivel científico y erudito logrado por el autor a través de sus razonamientos teóricos, demostrando iniciativa y originalidad a la hora de emprender la compleja labor con el verso didascálico. Fue organizando de una manera clara, rigurosa y sencilla los temas del poema, planteando una visión general de los principales problemas teóricos de la pintura en la Edad Moderna y guiándonos en la transmisión del conocimiento artístico. Mediante unos versos creados desde la admiración, respeto y estima por el arte de la pintura se aseguraba la continuidad del género didáctico-poético en nuestro país; el aparato paratextual del poema, por su parte, dotaba a todo el poema de una sólida estructura teórico-artística. Con ello saldaba la particular deuda personal que la cultura hispana había contraído en el contexto europeo y a la que aludía en su prólogo. Una completa tarea intelectual y literaria que debemos agradecer, dentro de sus numerosas contribuciones a la literatura artística dieciochesca, al ilustrado Diego Antonio Rejón de Silva. 


\section{BiBLIOGRAFÍA}

ÁLVAREZ BARRIENTOS, Joaquín. «La figura del escritor en el siglo XVIII». Cuadernos de Ilustración y Romanticismo, 1992, 2, pp. 13-30.

ÁLVAREZ BARRIENTOS, Joaquín. Los hombres de letras en la España del siglo XVIII. Apóstoles y arribistas. Madrid: Castalia, 2006.

ARCE, Joaquín. La poesía del siglo ilustrado. Madrid: Editorial Alhambra, 1985.

ARCE Y CACHO, Celedonio de. Conversaciones sobre la escultura. Intr. Cristóbal Belda Navarro. Madrid: Consejo General de la Arquitectura Técnica de España, 1996.

ARCO, Ricardo del. "Jovellanos y las bellas artes». Revista de Ideas Estéticas, 1946, 6, pp. 31-64.

BAEHR, Rudolf. Manual de versificación española. Eds. Klaus Wagner y Francisco López Estrada. Madrid: Gredos, 1973.

BaILs, Benito. Principios de matemática, donde se enseña la especulativa, con su aplicación a la dinámica, hidrodinámica, óptica, astronomía, geografía, gnomónica, arquitectura, perspectiva y al calendario. Madrid: Joaquín Ibarra, 1776.

BARÓN THAIDIgSMANn, Francisco Javier. Ideas de Jovellanos sobre arquitectura. Oviedo: Gobierno del Principado de Asturias, 1985.

Belda NaVARro, Cristóbal. La ingenuidad de las artes en la España del siglo XVIII. Murcia: Real Academia Alfonso X el Sabio, 1993.

BÉNÉZIT, Emmanuel. Dictionnaire des peintres, sculpteurs, dessinateurs et graveurs. Paris: Gründ, 1999.

CALVO SERRAller, Francisco. «El pincel y la palabra: una hermandad singular en el barroco español». En PORTús PÉREZ, Javier (ed.). El Siglo de Oro de la pintura española. Madrid: Biblioteca Mondadori, 1991, pp. 187-203.

CeÁn Bermúdez, Juan Agustín. Diccionario histórico de los más ilustres profesores de las Bellas Artes en España. Ed. José Miguel Morán Turina. Madrid: Akal, 2001.

Cebrián, José. «Poesía didáctica y ciencia experimental en la Ilustración española». Bulletin Hispanique, 1996, 98, pp. 121-135.

Cebrián, José. La Musa del Saber. La poesía didáctica de la Ilustración española. Madrid: Iberoamericana, 2004, pp. 81-144.

CERA BREA, Miriam. «Jovellanos y Ceán Bermúdez, hacia una historia de las artes en España». Anuario del Departamento de Historia y Teoría del Arte, 2014, 26, pp. 55-68.

Checa Cremades, Fernando y Morán Turina, José Miguel. "Las ideas artísticas de Diego de Saavedra Fajardo». Goya: Revista de Arte, 1981, 161-162, pp. 324-331.

CRESPo Delgado, Daniel. Un viaje para la Ilustración. El Viaje de España (1772-1794) de Antonio Ponz. Madrid: Marcial Pons, 2012.

CRESPO Delgado, Daniel. «Lectores y noticias sobre bellas artes en los papeles periódicos españoles de la Ilustración». En Maestre Maestre, José María; Díaz Gito, Manuel Antonio y ROMERo Ferrer, Alberto (eds.). Francisco Mariano Nipho. El nacimiento de la prensa y de la crítica literaria periodística en la España del siglo XVIII. Alcañiz-Madrid: Instituto de Estudios Humanísticos y CSIC, 2015, pp. 31-60.

EgIDO, Aurora. Fronteras de la poesía en el Barroco. Barcelona: Crítica, 1990.

Gallego Gallego, Antonio. Historia del grabado en España. Madrid: Cátedra, 1979.

GÁlLEgo SERRANO, Julián. Visión y símbolos en la pintura española del Siglo de Oro. Madrid: Cátedra, 1984.

García Felguera, María de los Santos. Viajeros, eruditos y artistas. Los europeos ante la pintura española del Siglo de Oro. Madrid: Alianza, 1991. 
LA PINTURA: POEMA DIDÁCTICO EN TRES CANTOS (1786) DE DIEGO ANTONIO REJÓN DE SILVA...

García López, David. "El Diccionario Histórico de los más ilustres profesores de las Bellas Artes en España». En Santiago Páez, Elena María (coord.). Ceán Bermúdez. Historiador del arte y coleccionista ilustrado. Madrid: Biblioteca Nacional de España-Centro de Estudios Europa Hispánica, 2016, pp. 225-245.

García Melero, José Enrique. Arte español de la Ilustración y del siglo XIX. En torno a la imagen del pasado. Madrid: Ediciones Encuentro, 1998.

GaYA NuÑo, Juan Antonio. Historia de la crítica de arte en España. Madrid: Ibérico Europea de Ediciones, 1975.

GaYA NuÑo, Juan Antonio. Vida de Acisclo Antonio Palomino: el historiador, el pintor: descripción y crítica de sus obras. Córdoba: Diputación Provincial, 1981.

GONZÁlEZ SANTOS, Javier. Jovellanos, aficionado y coleccionista. Gijón: Fundación Municipal de Cultura, Educación y Universidad Popular, 1994.

Guevara, Felipe de. Comentarios de la Pintura. Ed. A. Ponz. Madrid: D. Gerónimo Ortega, Hijos de Ibarra y Compañía, 1788.

HeNARES CUÉlLAR, Ignacio. La teoría de las artes plásticas en España en la segunda mitad del siglo XVIII. Granada: Secretariado de Publicaciones de la Universidad, 1977.

Hormigón BláNQueZ, Mariano. "Las matemáticas en la Ilustración española: su desarrollo en el reinado de Carlos III». En Fernández Pérez, Joaquín y GonZÁlez Tascón, Ignacio (eds.). Ciencia, técnica y estado en la España ilustrada. Madrid: Secretaría de Estado de Universidades e Investigación, 1990, pp. 265-278.

INSÚA, Marcela. "La falsa erudición en la Ilustración española y novohispana: Lizardi». Estudios Filológicos, 2011, 48, pp. 61-79.

InTERIÁN DE Ayala, Juan. El Pintor Christiano, y erudito, o tratado de los errores que suelen cometerse frecuentemente en pintar, y esculpir las Imágenes Sagradas. Ed. Luis de Durán y de Basteró. Madrid: Joachin Ibarra, 1782.

Iriarte, Tomás de. La Música. Poema. Madrid: Imprenta Real, 1789.

Jovellanos, Gaspar Melchor de. Memorias histórico-artísticas de arquitectura. Ed. Daniel Crespo Delgado y Joan Domenge i Mesquida. Madrid: Akal, 2013.

Jovellanos, Gaspar Melchor de. Elogio de las Bellas Artes. Intr. Javier Portús Pérez. Madrid: Casimiro, 2014.

LeÓn Tello, Francisco José y SAnZ SAnZ, María Virginia. La teoría española en la pintura en el siglo XVIII: el tratado de Palomino. Madrid: Universidad Autónoma, 1979.

León Tello, Francisco José y Sanz Sanz, María Virginia. Tratados neoclásicos españoles de pintura y escultura. Madrid: Universidad Autónoma, 1980.

LORENZO Álvarez, Elena de. Nuevos mundos poéticos: la poesía filosófica de la Ilustración. Oviedo: Universidad de Oviedo-Instituto Feijoo de Estudios del siglo XVIII, 2002.

Marías, Fernando. El siglo XVI. Gótico y Renacimiento. Madrid: Sílex, 1992.

Martínez-Burgos García, Palma. "El decoro. La invención de un concepto y su proyección artística». Espacio, Tiempo y Forma, serie VII Historia del Arte, 1988, 1, pp. 91-102.

MenÉndez Pelayo, Marcelino. Historia de las ideas estéticas en España. Madrid: Consejo Superior de Investigaciones Científicas, 1994.

Mengs, Antonio Rafael. Obras de D. Antonio Rafael Mengs. Publicadas por don Josep Nicolás de Azara. Madrid: Dirección General de Bellas Artes y Archivos, 1989.

Morán Turina, José Miguel. «El rigor del tratadista: Palomino y el Museo Pictórico». Anales de Historia del Arte, 1996, 6, pp. 267-284.

Mr. ReIfstein. "Sur la Peinture, avec l'expesé d'une nouvelle façon de peindre en Pastel». Journal Etranger, 1757, 50 (febrero), pp. 100-106. 
Navarrete Prieto, Benito. Murillo y las metáforas de la imagen. Madrid: Cátedra, 2017.

Palomino, Acisclo Antonio. Parnaso pintoresco laureado con las vidas de los pintores y estatuarios eminentes españoles. Madrid: Viuda de Juan García, 1724.

Peña Velasco, Concepción de la. Aspectos biográficos y literarios de Diego Antonio Rejón de Silva. Murcia: Colegio Oficial de Aparejadores y Arquitectos Técnicos, 1985.

PeÑa Velasco, Concepción de la. Rejón de Silva y el discurso ilustrado sobre la escuela de pintura española. Atrio, 2013, 19, pp. 69-82.

Plinio. Textos de Historia del Arte. Ed. Esperanza Torrego. Madrid: Visor, 1987.

PONZ, Antonio. Viage de España, o cartas, en que se da noticia de las cosas mas apreciables, $y$ dignas de saberse que hay en ella. Madrid: Joachim Ibarra, 1772.

PORTÚs PÉREZ, Javier. «Indecencia, mortificación y modos de ver en la pintura del Siglo de Oro». Espacio, Tiempo y Forma. Serie VII, Historia del Arte, 1995, 8, pp. 55-88.

Portús Pérez, Javier. Pintura y pensamiento en la España de Lope de Vega. Guipúzcoa: Nerea, 1999.

PORTús PÉREZ, Javier. «Tratados de pintura y tratados de imágenes sagradas en el Siglo de Oro». En Riello, José (ed.). Sacar de la sombra lumbre. La teoría de la pintura en el Siglo de Oro (1560-1724). Madrid: Abada Editores, 2012, pp. 21-31.

PORTús PÉREZ, Javier. "Painting and Poetry in Diálogos de la Pintura». En ANDrews, Jean; Roe, Jeremy y Wood, Oliver Noble (eds.). On Art and Painting. Vicente Carducho and Baroque Spain. Wales: University of Wales Press, 2016, pp. 71-90.

Rejón de Silva, Diego Antonio. La Pintura: Poema didáctico en tres cantos. Segovia: Imprenta de D. Antonio Espinosa de los Monteros, 1786.

Rejón DE SILVA, Diego Antonio. Diccionario de las nobles artes para instrucción de los aficionados, y uso de los profesores. Segovia: Imprenta de D. Antonio de Espinosa, 1788.

ReYes Gómez, Fermín de los. "El impresor Antonio Espinosa de los Monteros en Madrid: avance para su estudio". Revista General de Información y Documentación, 2004, 14, pp. 121-152.

Rubio lapaz, Jesús y Moreno Cuadro, Fernando. Escritos de Pablo de Céspedes. Córdoba: Diputación de Córdoba, 1998.

RUEDA, Ana. "Cartas y cartapacios: la crítica literaria del siglo XVIII ante la "vana erudición" del coleccionismo". Cuadernos de Ilustración y Romanticismo, 2015, 21, pp. 11-23.

SaAvedra Fajardo, Diego. Empresas políticas. Ed. Sagrario López. Madrid: Cátedra, 1999.

SABATIER DE CASTRES y BASSIN DE PRÉFORT, Antoine. Dictionnaire des origines, decouvertes, inventions et établissements, ou Tableau historique de l'origine et des progrès de tout ce qui a rapport aux sciences et aux arts. Paris: Moutard, 1777.

SARRAIH, Jean. "La notion de l'utile dans la culture espagnole à la fin du XVIII ${ }^{\mathrm{e}}$ siècle». Bulletin Hispanique, 1948, 50 (3-4), pp. 495-509.

Selles, Manuel; Peset, José Luis y LAfuente, Antonio. Carlos III y la ciencia de la Ilustración. Madrid: Alianza, 1988.

SEMPERE y GuARINOS, Juan. Ensayo de una biblioteca española de los mejores escritores del reinado de Carlos III. Madrid: Imprenta Real, 1789.

Tervarent, Guy de. Atributos y símbolos en el arte profano. Diccionario de un lenguaje perdido. Ed. José María Sousa Jiménez. Barcelona: Ediciones del Serbal, 2002.

TiCKNOR, George. History of Spanish Literature. New York: Frederick Ungar Publishing Co., 1849.

Úbeda De los CoBos, Andrés. «La Prehistoria de la Historia del Arte». En Historiografía del Arte Español en los siglos XIX y XX. Madrid: Alpuerto, 1995, pp. 128-130. 
LA PINTURA: POEMA DIDÁCTICO EN TRES CANTOS (1786) DE DIEGO ANTONIO REJÓN DE SILVA...

Úbeda De los Cobos, Andrés. Pensamiento artístico español del siglo XVIII. De Antonio Palomino a Francisco de Goya. Madrid: Aldeasa, 2001.

VASARI, Giorgio. Las Vidas de los más excelentes arquitectos, pintores y escultores italianos desde Cimabue a nuestros tiempos. Eds. Luciano Bellosi y Aldo Rossi. Madrid: Cátedra, 2014.

WincKelmann, Johann Joachim. Historia de las artes entre los antiguos. Ed. Alejandro Martínez Pérez. Madrid: Real Academia de Bellas Artes de San Fernando, 2014.

XAVIER DE Feller, François. Dictionnaire Historique des Hommes qui se sont fait un nom par leur génie, leurs talents, leurs erreurs ou leurs crimes. Eds. C.-I. Busson y C. Weiss. Paris: J. Leroux, Jouby et $\mathrm{C}^{\mathrm{e}}$ libraires - Gaume Freres Libraires, 1850. 
